\title{
THE APPLICATION OF SHALLOW SEISMIC REFRACTION SURVEYS TO MINING AND CIVIL ENGINEERING PROBLEMS. A CASE HISTORY
}

\author{
HARRY P. FORMANEK*
}

\begin{abstract}
During 1978, a shallow seismic refraction survey was carried out for Grupo Camargo Correa in the vicinity of Vazante, Estado de Minas Gerais, Brasil.

The project achieved the objective of detailed mapping of the subsurface geology of an area covered by residual and transported soils, underlain by deeply weathered, folded and faulted rocks of the Precambrian Bambui Group.

Nearly 100 line kilometers of seismic refraction profiling was completed, covering an area of 50 square kilometers. The very irregular bedrock interface and the presence of dipping refractors, required good quality seismic recordings and methods of interpretation suited to complex geologic situations.

The operating procedures and methods of interpretation of seismic refraction data, presented in this paper, are applicable to geotechnical investigations for mining and civil engineering projects where great detail of the soil, weathering and bedrock conditions is required.
\end{abstract}

RESUMO Durante 1978, foi desenvolvido para o Grupo Camargo Corrêa, nas vizinhanças de Vazante, estado de Minas Gerais, Brasil, um trabalho de refração sísmica rasa.

Os objetivos do Projeto foram alcançados, com o mapeamento detalhado da geologia de subsuperficie de uma área com cobertura residual e de solos transportados sobrepostos a rocha do Grupo Bambui, do Precambriano, profundamente intemperizadas, dobradas e falhadas.

Cerca de $100 \mathrm{~km}$ de linhas em perfis de refração sísmica foram completados, abrangendo uma área de $50 \mathrm{~km}^{2}$. A interface do "bedrock" muito irregular e a presença de refratores inclinados exigiram uma boa qualidade dos registros sísmicos e métodos de interpretação aplicáveis a situações complexas.

O procedimento de operação e os métodos de interpretação dos dados de refração sísmica apresentados neste artigo podem ser utilizados em investigações geotécnicas de projetos de mineração e engenharia civil, onde são requeridos conhecimentos em grande detalhe dos perfís de solo e alteração e das condições do "bedrock".

INTRODUCTION The seismic refraction method is widely used in geotechnical investigations for dams, road construction, bridges, nuclear power stations and other large or sensitive civil engineering structures. The application of this method is less common in exploration and mining, even though the information sought is essentially the same: i.e., the nature and depth of overburden and weathering; the physical properties and attitude of the concealed rock formations; the presence of faults and other geologic phenomena.

Refraction surveys measure the speed of seismic waves travelling through the ground. Seismic waves travel at different speeds in materials possessing different elastic properties, which may vary from less than $500 \mathrm{~m} / \mathrm{s}$ in unconsolidated soils to over $7000 \mathrm{~m} / \mathrm{s}$ in certain limestones and intrusive rocks. Seismic wave velocity if a function of the physical properties of geologic formations, the density, grain size, pore space and mineral constituents of rocks or unconsolidated sediments, the degree of fracturing and weathering and many others. Accurate measurements and interpretations of seismic velocities will therefore yield important informations on the overburden and weathering profiles, the characteristics of burried rock formations and under favourable circumstances - can be used to identify faults and other geologic phenomena.

The interpretation of seismic refraction records, as of other geophysical methods, does not always provide unique solutions. A complete appreciation of the capabilities and limitations of this method is essential. The different physical properties influencing the seismic velocity have to be identified and separated. The possible existence of "blind layers" must be

\footnotetext{
* Grupo Camargo Correa, Rua Funchal, 160, 04551 Vila Olimpia, São Paulo, Brasil. or P.O. Box 62383, Marshalltown, 2107, Johannesburg, South Africa
} 
recognized. Raypath models should be developed taking into account the local geologic and geotechnical conditions. And, finally, a sufficient amount of geologic and boring data should be available, against which interpretations of seismic refraction data can be checked and adjusted if necessary.

If all these conditions are met, a well executed seismic refraction survey can yield a wealth of geologic and geotechnical informations, which can not be obtained with any other or combination of other geophysical methods at comparable cost.

\section{SEISMIC REFRACTION SURVEY VAZANTE}

The situation at the Vazante project is all too familiar to geologists and geotechnical engineers:

The topography is undulating to hilly, the flat areas being covered by scree and transported sediments. Fresh rock outcrops are scarce consisting of a few isolated occurrences of erosion resistant, massive dolarenite.

Geologically, the Vazante area is underlain by the Precambrian Bambui Group, a sequence of slightly metamorphosed shales, siltstones, algal-dolomites and dolarenties. The softer members of this sequence, shales and siltstones, are weathered to a depth exceeding 80 metres in places. The Bambui Group is folded in the area under investigation, dipping generally NW at $0^{\circ} 20^{\circ}$. Numerous minor and major faults, and fault zones are present.

A knowledge of the subsurface position of the major dolarenite bodies was considered essential to the success of the exploration venture. The dolarenites were deemed to have a high seismic velocity in contrast, it was hoped, with lower velocity shales and siltstones in which they occur.

This assumption was confirmed by a test survey which indicated that the subsurface topography, the major rock units, faults and other geologic anomalies could be mapped with reasonable accuracy and correlated with borehole data. It was consequently decided to proceed with a detailed seismic refraction programme, of approximately 100 line kilometres covering an area of 50 square kilometres. Lines were initially spaced one kilometre apart perpendicular to the strike of the formation. Intermediate lines, 500 metres apart, were shot in areas requiring greater detail.

The objective of the project amounted to continuous geologic profiling and mapping with the greatest possible detail of the soil and overburden profile, of the depth of weathering, of the overburden/bedrock interface and of the bedrock geology and structure. To achieve these objectives, close geophone and shot spacing was required and interpretation methods had to be adapted for mapping of the very irregular subsurface geology.

FIELD OPERATIONS, PROCEDURES AND PROBLEMS The lay-out of geophones and shot points used during the major part of this seismic refraction programme is shown in Fig. 1.
Each spread of $287,5 \mathrm{~m}$ comprised 24 geophones spaced at $12,5 \mathrm{~m}$ intervals. Adjoining spreads overlapped with 6 geophones. This rather generous overlap was dictated by the requirement of accurate arrival time correlation of adjoining spreads, necessary for the interpretation methods used during the study.

Shot points were located in the centre of the spreads (Al, Bl), at a distance of $25 \mathrm{~m}$ from the end of the spreads (A2, A4; B2, B4) and at a distance of $250 \mathrm{~m}$ from the end of the spreads (A3, A5: B3, B5). On those lines where overburden and/or weathering extended to a depth exceeding $80 \mathrm{~m}$, long outshots were fired from a distance of $525 \mathrm{~m}$ to achieve the necessary penetration.

The explosive charges were electrically detonated, the firing triggering a time break on the recorder.

A SIE RS 44 system with gain control and filters was used to record the seismic arrivals, from 24 channels simultaneously, on light sensitive paper.

In shallow seismic refraction work, only the "first arrivals" are generally used for the interpretations. It is an essential requirement that the seismic recordings are of a good quality and that the "first arrivals" can be determined with great accuracy. In the present study, recordings were considered adequate if the "first arrivals" could be determined with an accuracy of $1 \mathrm{~ms}$.

One or more of the following factors contributed to poor seismic records: Inaccurate filter setting and gain control; instrument noise; external noise; adverse geologic conditions. Of these, all but adverse geologic conditions could be reduced or eliminated with careful operating procedures so that recordings of a good quality could be obtained.

The most persistent problems were "crossfeed" and a high noise to signal ratio.

"Crossfeed" as used in this report are signals unrelated to seismic arrivals. Centre shots and near out-shots were sometimes affected by "crossfeed" in which case the explosion or the resultant airblast triggered electrical signals in the system which would arrive prior to the seismic signals. A reduction in the size of the explosive charge and an increase in the distance of the shotpoint from the geophone spread, generally eliminated this problem.

Instrument or external noise due to wind, agricultural or human activities could adversely affect the quality of the seismic recordings. Careful attention to correct operating procedures, elimination of instrumental and human noise, trial and error with different filter settings and gain control and shooting during periods of quiet atmospheric conditions, generally helped to reduce noise to acceptable levels.

Geologic conditions adversely affecting the quality of the seismic records were twofold:

The presence of a thick cover of loose, unconsolidated soil in karstic areas absorbed much of the force of the blast, filtering out the high frequiencies, with the result that first arrivals were no longer discernible 


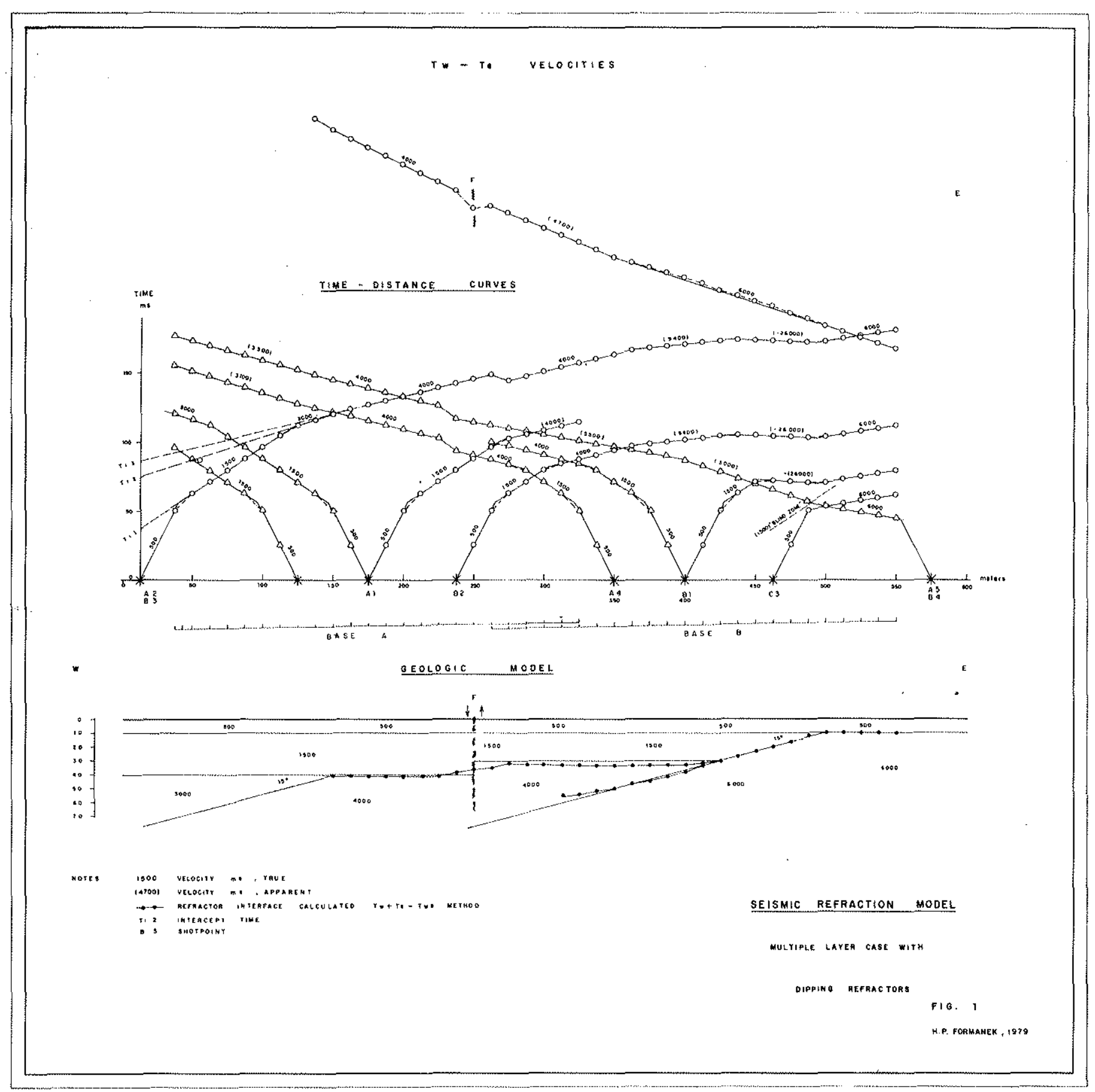

Figure 1 -

some distance from the shotpoint. The placing of explosive charges in deeper drill holes and the use of high velocity explosives improved but seldom elminated this problem.

Another problem, inherent in the seismic refraction method, is the simultaneous arrival of seismic signals from two or more refractors which may cancel or amplify each other. The incidence of signal inter ference is not serious in the case of horizontal stra- tigraphy but the first arrivals may no longer be identifiable under complex geologic conditions such as alternating. narrow beds, fault and karst zones. When this occured, additional shots were fired for the in terpretation of difficult geologic situations.

The foregoing indicates the need for a well planned and executed seismic refraction survey with flexibility, attention to detail and - experience. There is no substitute for high quality seismic refraction records. 
INTERPRETATION The principles of seismic refraction prospecting and interpretation techniques are covered in a special volume by the Society of Exploration Geophysicists, published in 1967.

The present paper assumes familiarity with the wavepath geometry of seismic refraction and deals with those methods of interpretation applicable to complex geologic situations and dipping refractors.

Let us consider a multiple layer seismic refraction model which simulates the geologic conditions encountered at the Vazante project (Fig. 1): A low velocity soil cover $(500 \mathrm{~m} / \mathrm{s})$ followed by an intermediate layer of alluvium or deeply weathered rocks $(1500 \mathrm{~m} / \mathrm{s})$. The bedrock interface is irregular and the bedrock consists of dipping layers of shale $(3000 \mathrm{~m} / \mathrm{s})$, siltstone $(4000 \mathrm{~m} / \mathrm{s})$ and dolarenite $(6000 \mathrm{~m} / \mathrm{s})$.

Refraction paths cross boundaries between materials having different velocities, in such a way that energy travels from shotpoint to receiver in the shortest possible time as required by Fermat's principle. If the shortest time ray paths are calculated and plotted for each shotpoint and geophone, one arrives at the timedistance curve shown in Fig. 1.

The velocities of the soil and intermediate layers can now recalculated through the slope $1 / \mathrm{V}$ of the straight line segments of the time-distance plots, representing the relationship $T=x / \mathrm{V}$ (where $T$ is the arrival time and $x$ is the horizontal distance).

It should be noted that the $1500 \mathrm{~m} / \mathrm{s}$ layer is not present on the time-distance curve from shotpoint C3. This phenomenon, known as the "blind zone", presents one of the most difficult problems in seismic refraction interpretations. If the existence of a "blind layer" goes unrecognized, serious errors in depth calculations will result.

Under conditions of horizontal or gently dipping beds, the apparent velocities from reciprocal time-distance segments can be used to determine the true bedrock velocities. However, when the refractor interface is irregular or steeply dipping and the overburden velocity is variable, best-fit straight line segments are difficult to find and the apparent velocities may have negative values. In these cases, no meaningful results can be obtained by traditional interpretation methods.

In the present study, the "plus-minus" method was used to determine the bedrock velocities. The method was developed by Thornburgh (1930) and later applied by Hagedoorn (1959) and Hawkins (1961). In principle, the addition of the travel times from reciprocal shotpoints to each geophone gives the relative depths and their subtraction gives the velocities of the refractor.

In Fig. 1, the reciprocal travel times from the longest outshots were subtracted to yield a new curve $t_{\mathrm{W}}-t_{\mathrm{E}}$ velocities. The slope of this curve represents $1 / 2$ of the true bedrock velocities.

The accuracy of velocity determinations by the "plus-minus" method depends on a correct identifi- cation of the point on the refracting surface, from which the signal received at the geophone originates. In other words, the raypath has to be known so that the horizontal off-set can be determined and reciprocal travel times from the same refracting point can be combined. If this criterium is met, the "plus-minus" method will yield good approximations of true bedrock velocities.

First arrivals from reciprocal shots may originate from different refractors as illustrated in Fig. 1 between 250 and 350 metres. If time-distance segments from different refractors are combined, as has been done in this case, "mixed" velocities will result. Additional shots and considerable judgement are necessary to resolve ambiguities in the interpretation of seismic refraction records.

The depths to the refractors can be calculated from the intercept time $\left(t_{i}\right)$ or from the crossover distance which can be graphically or numerically determined from the time-distance plot. Methods for the calculation of the depths of progressively deeper refractors have been presented in many publications (1). Depth calculations from the intercept time are applicable to horizontal or slightly dipping refractors and have been used in the present study for the depth calculations of the soil, intermediate and weathering layers.

For continous profiling of the very irregular overburden/bedrock interface the "time-depth" method of interpretation has been used (Hawkins, 1961). The time - depth $(t)$ at a geophone station is obtained by adding the travel times from reciprocal shotpoints to the geophone stations, subtracting the total shotpoint to shotpoint travel time and halving the results. The depth $z$ to the refractor is calculated through the formula

$$
z=t \cdot V_{0} /\left(1-V_{0}^{2} / V_{1}^{2}\right)^{1 / 2}
$$

where 1 is the travel time between refractor and geophone, $V_{0}$ is the overburden velocity and $V_{1}$ is the bedrock velocity.

This method avoids the ambiguities of other interpretation methods in that only the overburden velocity $V_{0}$, the bedrock velocity $V_{1}$ and the approximate position of the refracting point relative to the geophone must be known. If the ratio $V_{0} / V_{1}$ is small and the refracting surface reasonably horizontal and at shallow depths, the raypath will be close to vertical and the reciprocal arrival times from the same geophone can be combined. When the refractor surface is steeply dipping and irregular the "time-depths" must be adjusted for the horizontal off-set of the raypath.

The "time-depth" method for depth calculations is very sensitive to changes in the average overburden velocity $V_{0}$. An adequate number of closely spaced shots is therefore required for the accurate determination of overburden velocities at frequent intervals.

In our refraction model (Fig. 1) the depths to the bedrock refractor were recalculated using as input the 
theoretical travel times, overburden velocities calculated from the intercept times and bedrock velocities calculated by the "plus-minus" method. The recalculated depths values were within $10 \%$ of the true depth of the bedrock refractor.

GEOLOGIC RESULTS Detailed interpretations of seismic refraction data are shown in Fig. 2 and 3. These profiles were selected to illustrate the capabilities as well as limitations of the seismic refraction method.

The western part of line 7500 (Fig. 2) is characterized by rather quiet geologic conditions, a three media case with nearly flat refractor interfaces. The overburden profile, bedrock interface and bedrock velocities can be reliably estimated using methods briefly described in the previous chapter. In the eastern part, velocities increase gradually with depth until a low velocity bedrock (shale or siltstone) is reached. Between 3420 and $3540 \mathrm{~m}$, the apparent bedrock velocities are as low as $2100 \mathrm{~m} / \mathrm{s}$. As this apparent velocity is similar to the true velocity of the weathered zone, the depth to the bedrock interface can no longer be determined. A disturbance is clearly expressed on all reciprocal time-distance curves in the central part of the profile. The significantly earlier arrivals at geophone 3412 , indicate a high in the subsurface topography and/or a narrow, subvertical high-velocity rock formation. As this anomaly also occurs within the otherwise uniform soil profile, a fault with quartz infilling was interpreted. This was confirmed during subsequent field and drilling investigations.

Line 4000 (Fig. 3) shows more complex geology and a very irregular and steeply dipping bedrock refractor. As in the previous example, the western part is represented by fairly quiet conditions which allows an easy interpretation of the soil, overburden and weathering profile and bedrock velocities. The dip of the bedrock formation was inferred from the dipslope of the high velocity layers. The bedrock is overlain by a narrow zone of weathered and/or fractured rocks $(2000 \mathrm{~m} / \mathrm{s})$ which becomes a "blind zone" on some time-distance segments. A major fault zone occurs in the central part of the profile where an irregular and steeply dipping subsurface topography results in a very complex time-distance graph which defies interpretation by standard methods. Under these circumstances, approximate solutions can only be found by the construction of wave trajectories, working backward from the geophone locations to the shotpoints. Although line 7500 has been shot over a geologically complex area, a drill hole found a satisfactory correlation between predicted and actual overburden profile, refractor depth and bedrock characteristics.

The geologic results of this seismic refraction programme, part of which are graphically presented in Figs. 4 and 5, can be summarized as follows:

The soil, overburden and weathering profile was determined in considerable detail. This allowed identification of and correlation with the underlying rock formations.

The bedrock interface was mapped with an accuracy estimated at $10-15 \%$ in shallow areas and at $20 \%$ in areas where overburden and weathering exceeded $50 \mathrm{~m}$. Similar as in the interpretation of geomorphological data, this detailed profiling of the bedrock refractor has proved to be invaluable for the interpretation of the lithology and structure of the subsurface geology.

Major rock units were mapped under considerable overburden cover. High velocity beds of a minimum dimension of 25 metres were positively identified.

Numerous faults, karst zones and other geologic anomalies were mapped and confirmed during subsequent field investigations and drilling operations.

This seismic refraction survey provided geologic information of such detail as would have been obtained only through the drilling of a large number of boreholes at many times the cost of this survey.

Acknowledgement The author is indebted to Cia. Administradora Morro Vermelho, Grupo Camargo Corrêa, for permission to publish this paper. Progeol, a subsidiary of Western Geophysical, was responsible for the field work and the preliminary interpretations of the seismic refraction programme at Vazante. 


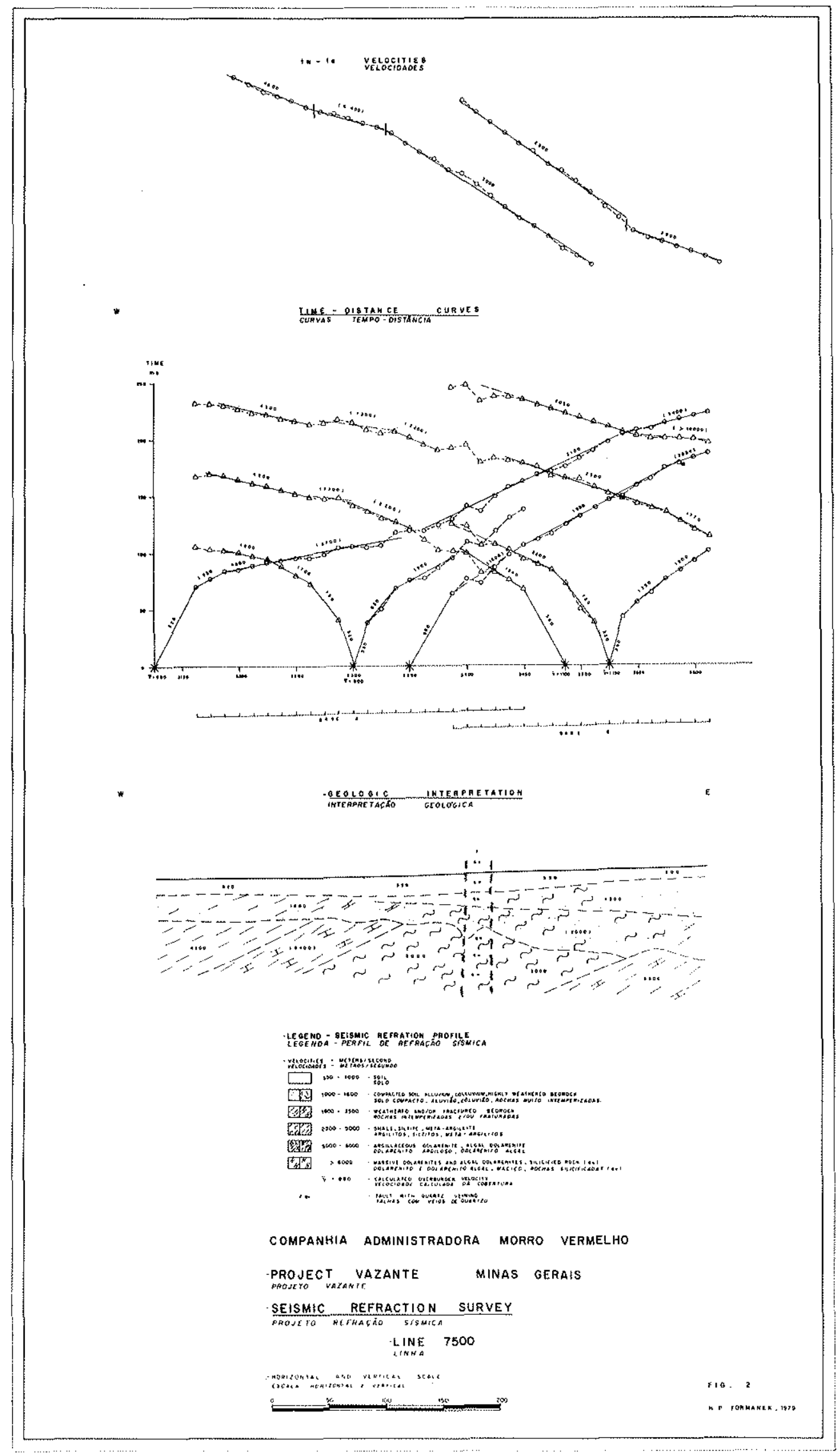

Figure 2-- 

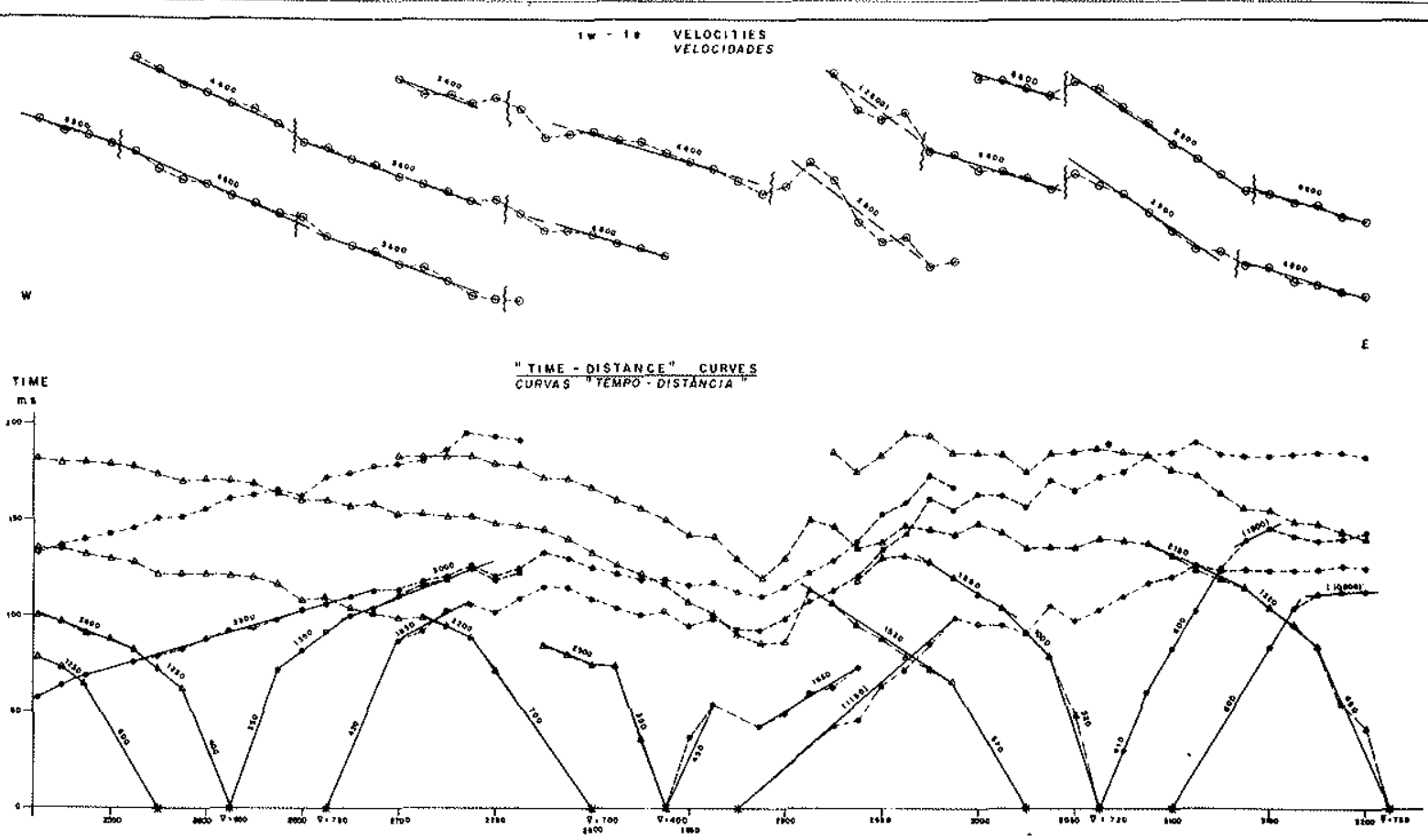

xit"
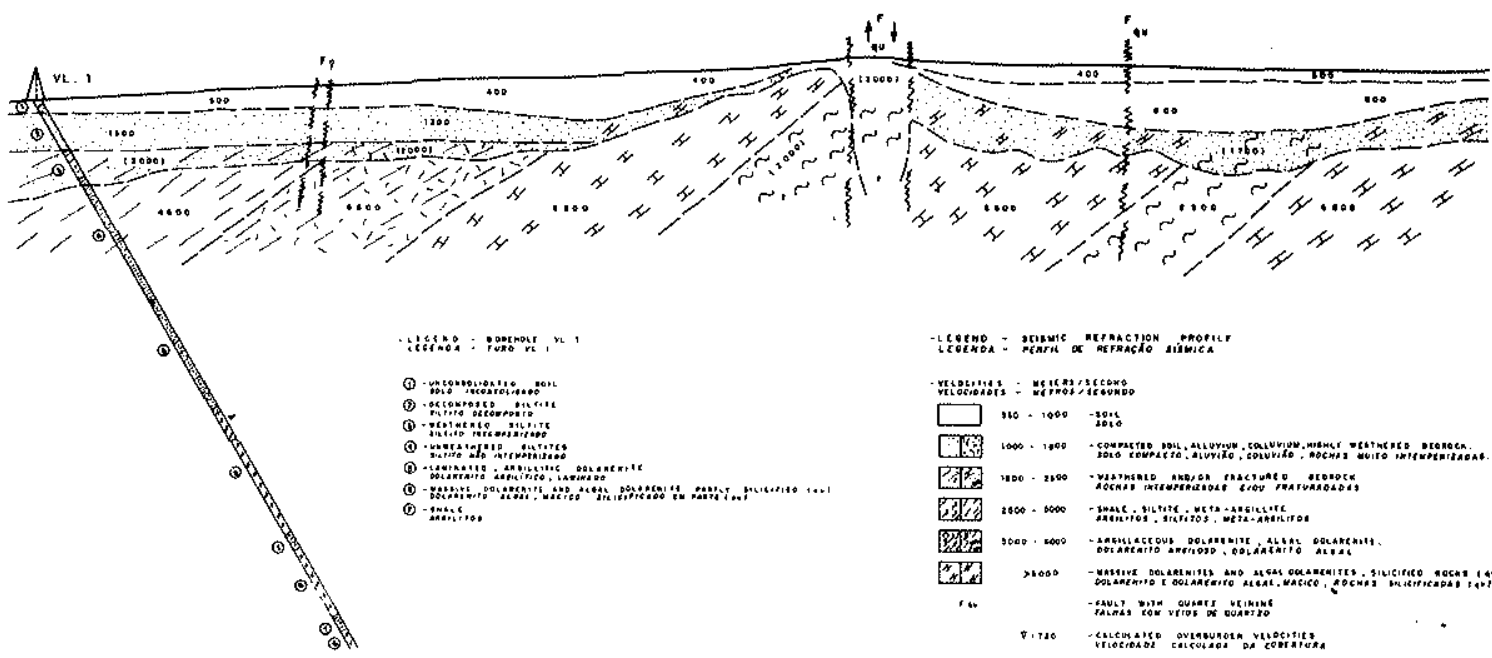

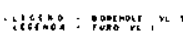

(1) .4.

(1)

-

-

(1) - Mtisis.o.

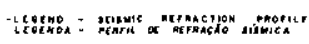

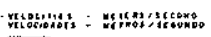

$\square \quad 106-1000 \quad-30 \%$

7T.

P限

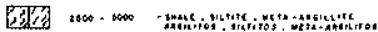

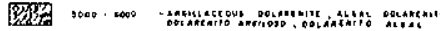

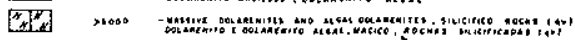

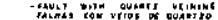

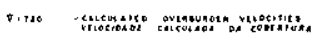

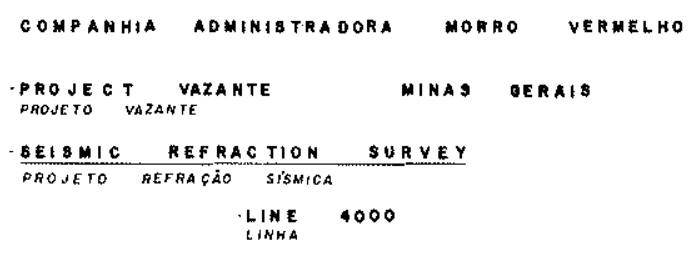

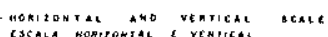

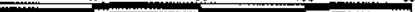




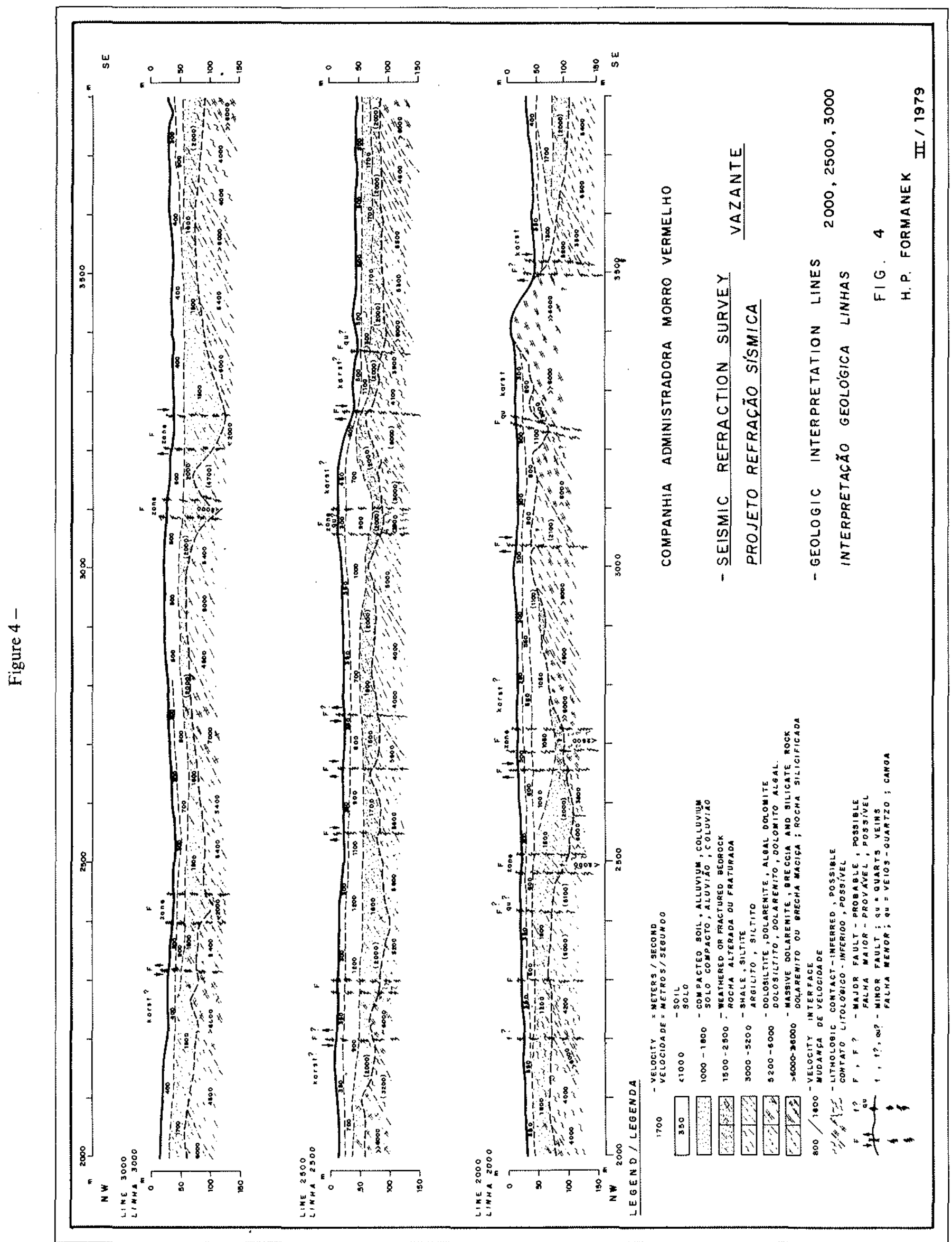


w

[

i

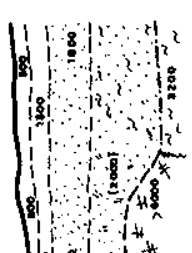

$-\quad c^{2}$

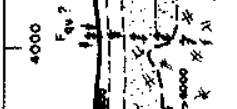

$\int 0$

(2)

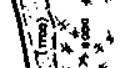

$a^{2+x} \times x$

$\sqrt{1+x^{2} x^{2}}$

Itin

(tin

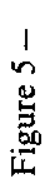

集

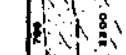

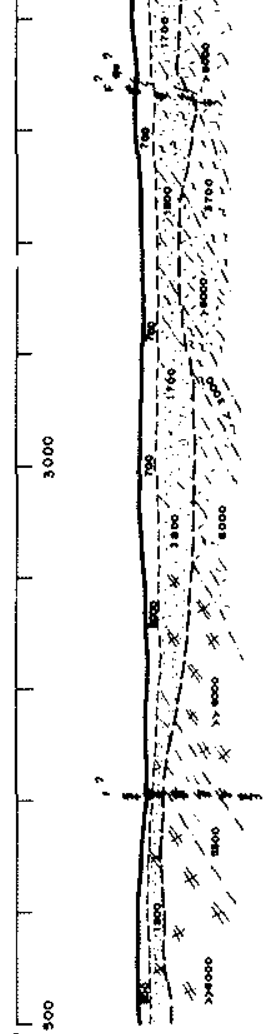

$\angle \frac{8}{2}$

$\because:$

₹

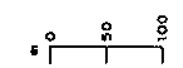

1018

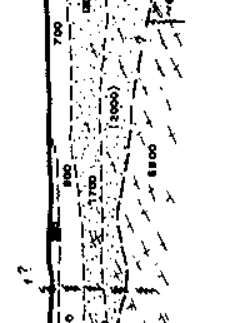

Isitit

1.8.

an

i:

照果

10

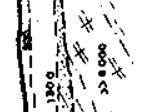

然

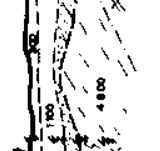

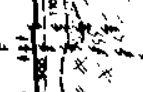

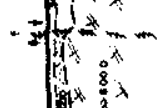

iif f $^{2}$

in

in

14:

14*

$=0$

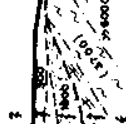

$\therefore$.

$=4 \begin{aligned} & 0 . \\ & 0\end{aligned}$

in 40

and

in

船?

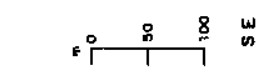

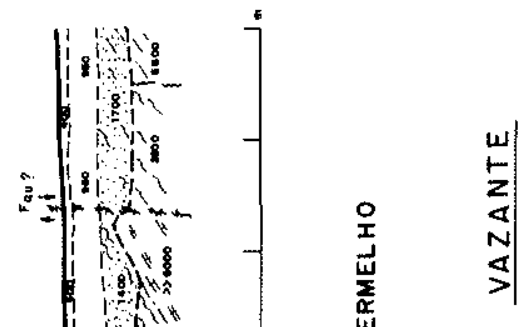

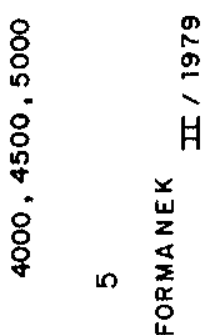

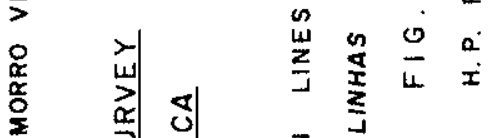

की

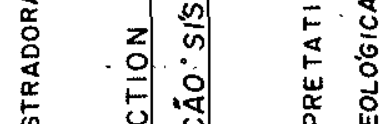

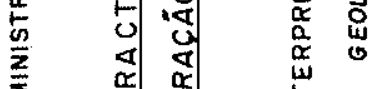

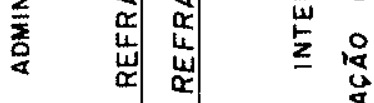

$\frac{4}{1}$
$\frac{2}{2}$
$\frac{0}{2}$
0

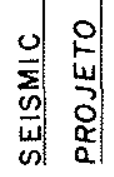

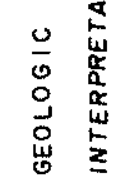

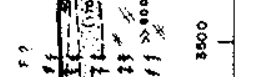

皮

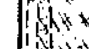

fio

Sin

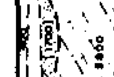

18

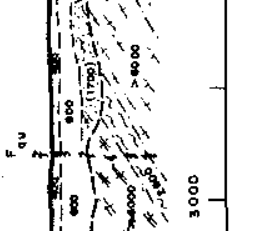

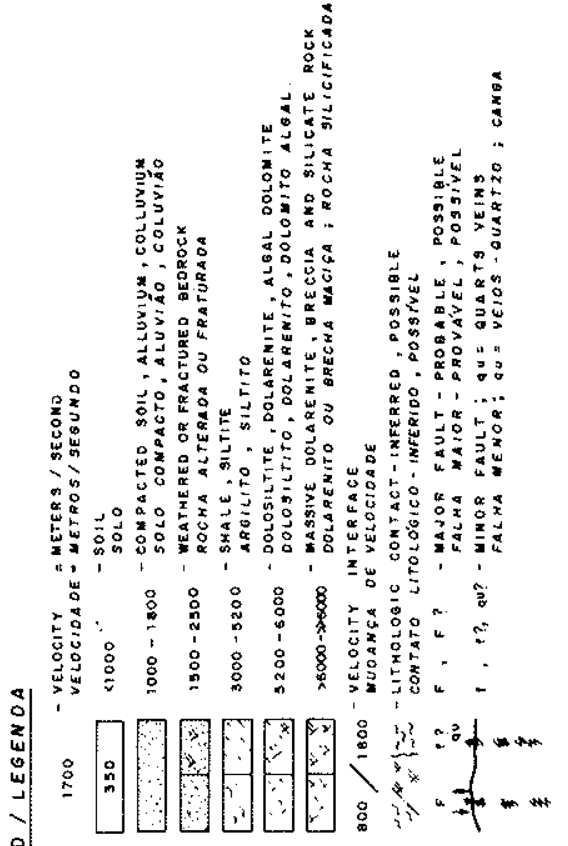

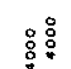

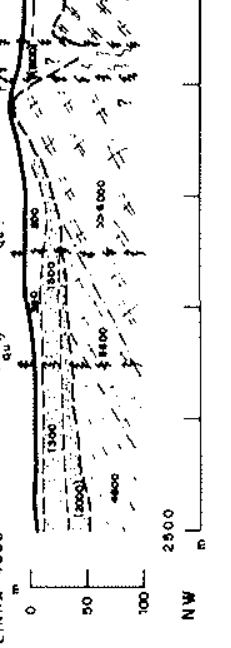




\section{REFERENCES}

Society of Exploration Geophysicits: "Seismic Refraction Prospecting"; A.W. Musgrave (ed.); Banta, Manasha, Wisc., 1967.

HALES, F.W. - 1958 - "An accurate Graphical Method For Interpreting Seismic Refraction Lines"; Geophys. Prospect.; vol. 6, n. ${ }^{\circ} 3$.

HAGEDOORN, J.G.; "The Plus-Minus Method of Interpreting Seismic Refraction Sections; Geophys. Prospect. :

HAWKINS, L.V - 1961 - "The Reciprocal Method of Routine Shallow Seismic Refraction Investigations"; Geophysics: vol. 26, n. ${ }^{\circ} 6$.

HAWKINS, L.V. and MAGGS, D. - 1961 - "Nomograms for Determining Maximum Errors and Limiting Conditions in Seismic Refraction Survey with a Blind-Zone Problem"; Geophys. Prospect.; vol. 9, n. ${ }^{\circ} 4$.

MERRICK N.P. et al - 1978 - "A blind zone solution to the Problem of Hidden Layers Within a Sequence of Horizontal or Dipping Refractors"; Geophysic. Prospect.; vol. 26. THORNBURGH, H.R. - 1930 - "Wave-Front Diagrams ins Seismic Interpretation"; Bull. Am. Assoc. Petrol. Geol.; vol. 14. 